\title{
The effects of 8 weeks of heavy resistance training and branched-chain amino acid supplementation on body composition and muscle performance
}

\author{
Mike Spillane*, Christamarie Emerson, Darryn S Willoughby
}

From International Society of Sports Nutrition: 10th Annual ISSN Conference and Expo

Colorado Springs, CO, USA. 14-15 June 2013

\section{Purpose}

This study determined the effects of eight weeks of heavy resistance training combined with branched-chain amino acid (BCAA) supplementation on body composition and muscle performance.

\section{Methods}

Nineteen non-resistance-trained males resistance-trained (3 sets of 8-10 repetitions) four times/week for eight weeks while also ingesting $9 \mathrm{~g} /$ day of BCAA or $9 \mathrm{~g} /$ day of placebo (PLAC) on exercise days only (half of total dose $30 \mathrm{~min}$ before and after exercise). Data were analyzed with separate $2 \times 2$ ANOVA $(\mathrm{p}<0.05)$.

\section{Results}

For total body mass, neither group significantly increased with training $(\mathrm{p}=0.593)$, and there also were no significant changes in total body water $(\mathrm{p}=0.517)$. Also, no training- or supplement-induced $(\mathrm{p}=0.783)$ changes occurred with fat mass or fat-free mass $(\mathrm{p}=0.907)$. Upper-body $(\mathrm{p}=0.047)$ and lower-body strength $(\mathrm{p}=$ $0.044)$ and upper- $(\mathrm{p}=0.001)$ and lower-body muscle endurance $(\mathrm{p}=0.013)$ were increased with training; however, these increases were not different between groups ( $\mathrm{p}>0.05)$.

Exercise and Biochemical Nutrition Lab, Department of Health, Human Performance, and Recreation, Baylor University, Waco, TX 76798, USA

\section{Conclusion}

When combined with heavy resistance training for eight weeks, $9 \mathrm{~g} /$ day of BCAA supplementation, half given $30 \mathrm{~min}$ before and after exercise, had no preferential effects on body composition and muscle performance.

Published: 6 December 2013

doi:10.1186/1550-2783-10-S1-P25

Cite this article as: Spillane et al:: The effects of 8 weeks of heavy resistance training and branched-chain amino acid supplementation on body composition and muscle performance. Journal of the International Society of Sports Nutrition 2013 10(Suppl 1):P25.
Submit your next manuscript to BioMed Central and take full advantage of:

- Convenient online submission

- Thorough peer review

- No space constraints or color figure charges

- Immediate publication on acceptance

- Inclusion in PubMed, CAS, Scopus and Google Scholar

- Research which is freely available for redistribution

Submit your manuscript at www.biomedcentral.com/submit 